\title{
Trichostrongylina (Nematoda, Heligmosomoidea) coparasites in Dasyprocta fuliginosa Wagler (Rodentia, Dasyproctidae) from Brazil, with the re-establishment of the genus Avellaria Freitas 8 Lent and the description of two new species
}

\author{
Marie C. Durette-Desset ${ }^{\prime}$; Alessandra Q. Gonçalves ${ }^{2} \&$ Roberto M. Pinto ${ }^{3}$ \\ ${ }^{1}$ Département de Systématique et Evolution, Muséum National d'Histoire Naturelle. UMR 7138 Associée au CNRS, CP 52, \\ 61, Rue Buffon 75231 Paris cedex 05, France. \\ ${ }^{2}$ Laboratório de Doenças Parasitárias, Departamento de Medicina Tropical, Instituto Oswaldo Cruz, Avenida Brasil 4365, \\ 21045-900, Rio de Janeiro, Rio de Janeiro, Brasil. \\ ${ }^{3}$ Laboratório de Helmintos Parasitos de Vertebrados, Departamento de Helmintologia, Instituto Oswaldo Cruz, Avenida \\ Brasil 4365, 21045-900, Rio de Janeiro, Rio de Janeiro, Brasil. CNPq research fellow. Corresponding author. \\ E-mail: rmpinto@ioc.fiocruz.br
}

\begin{abstract}
Two new tichostrongylid nematodes of the family Viannaiidae Durette-Desset \& Chabaud, 1981 coparasites in Dasyprocta fuliginosa Wagler, 1832 from the State of Amazonas, Brazil, are described: Viannella trichospicula sp. nov. is differentiated from the other species of the genus by the extreme slenderness of its spicules. Avellaria intermedia sp. nov. is distinguished from the single type species Avellaria avellari Freitas \& Lent, 1934, by a smaller number of cuticular ridges (17 versus 27 ), a higher ratio of spicule length/ body length ( $8 \%$ versus $5.6 \%$ ) and spicules with a single tip. This genus, synonymized with the genus Viannella Travassos, 1918, by DurETTE-DesSET (1968) is re-established, the female being didelphic. It is the first record of a nematode of the family Viannaiidae in a host of the family Dasyproctidae Bonaparte, 1838.

KEY WORDS. Avellaria intermedia sp. nov.; Brazil, Caviomorpha; nematodes; rodents;Viannaiidae; Viannella trichospicula sp. nov.
\end{abstract}

RESUMO. Trichostrongylina (Nematoda, Heligmosomoidea) co-parasitos em Dasyprocta fuliginosa Wagler (Rodentia, Dasyproctidae) do Brasil, com o restabelecimento do gênero Avellaria Freitas \& Lent e a descrição de duas novas espécies. Dois novos nematóides tricostrongilídeos da família Viannaiidae Durette-Desset \& Chabaud, 1981 coparasitos em um espécime de Dasyprocta fuliginosa Wagler, 1832 do Estado do Amazonas, Brasil, são descritos: Viannella trichospicula sp. nov. distingue-se das espécies do gênero, pelos espículos extremamente delgados. Avellaria intermedia sp. nov. diferencia-se da espécie tipo e única do gênero Avellaria avellari Freitas \& Lent, 1934, pelo menor número de arestas cuticulares (17 comparado a 27), pela maior relação entre o tamanho do espículo e o comprimento do corpo ( $8 \%$ comparado a 5,6\%) e espículos com extremidade única. Este gênero, que havia sido considerado sinônimo de Viannella Travassos, 1918, por DuRETTE-Desset (1968), é restabelecido; as fêmeas são didelfas. Este é o primeiro registro de um nematóide da família Viannaiidae em um hospedeiro da família Dasyproctidae Bonaparte, 1838.

PALAVRAS-CHAVE. Avellaria intermedia sp. nov.; Brasil; Caviomorpha; nematóides; roedores; Viannaiidae; Viannella trichospicula sp. nov.

The agoutis have been investigated mainly for the role they play in the spreading of severe sylvatic zoonoses (RiBEIRo \& Barretto 1977, Rebollar-Telles et al. 1996, Sherlock 1996, LAINSON 1997, RodRIGUes-Silva et al. 2002).

Presently, 12 species of Pudicinae (Heligmonellidae) distributed in four genera (Durettestrongylus Guerrero, 1982, Fuellebornema Travassos \& Darriba, 1929, Heligmostrongylus Travassos, 1917 and Pudica Travassos \& Darriba, 1929) have been described on the basis of nematodes recovered from specimens of the genus Dasyprocta Illiger, 1811 from Brazil, Colombia, Venezuela and Paraguay. Seven species are parasitic in Dasyprocta leporina (Linnaeus, 1758): Fuellebornema agoutii (Neiva, Cunha \& Travassos, 1914) Travassos \& Darriba, 1929, Fuellebornema neivai Cassone \& Durette-Desset, 1991 (= F. agoutii sensu Travassos, 1937 nec Neiva, Cunha \& Travassos, 1914), Fuellebornema minor Travassos, 1937, Fuellebornema almeidai 
Travassos, 1937, Heligmostrongylus sedecimradiatus (Travassos, 1917) and Pudica pudica (Travassos, 1921) from Brazil and Durettestrongylus ojastii Guerrero, 1982 from Venezuela; three species in D. fuliginosa Wagler, 1832: Fuellebornema granulosa Durette-Desset, 1970, Fuellebornema bocqueti Durette-Desset, 1970 and $P$. pudica from Colombia; and five species in Dasyprocta azarae Lichtenstein, 1823: F. granulosa, Fuellebornema demarsae Cassone \& Durette-Desset, 1991, P. pudica, Pudica gonosoma Cassone \& Durette-Desset, 1991 and Durettestrongylus baudi Cassone \& Durette-Desset, 1991 from Paraguay (Neiva et al. 1914, Travassos $1917,1921,1937$, Travassos \& Darriba 1929, Durette-Desset 1970a, Guerrero 1982, Cassone \& Durette-Desset 1991).

Several examples of the occurrence, in a single individualhost, of coparasite species (congeneric or belonging to the same sub-family) have already been revealed in caviomorph rodents. Cases have been reported from Proechimys spp. (DuretTE-Desset 1970b, R'Kha \& Durette-Desset 1990, Durette-Desset et al. 2001), D. fuliginosa (Durette-Desset 1970a) and from D. azarae (CASSONE \& Durette-Desset 1991).

This paper is related to trichostrongylid nematodes recovered from an agouti, with the description of two new species, one in the genus Viannella Travassos, 1918 and another in the genus Avellaria Freitas \& Lent, 1934, which is re-established here.

Moreover, this is the first record of a nematode of the family Viannaiidae Durette-Desset \& Chabaud, 1981 in a host of the family Dasyproctidae Bonaparte, 1838, taking into account that representants of this group were previously found infected only with trichostrongylids of the family Pudicinae Durette-Desset, 1971.

\section{MATERIAL AND METHODS}

Capture and necropsy of the host specimen were authorized by the IBAMA (Instituto Brasileiro de Meio Ambiente e Recursos Renováveis), Brazil, process no. 02001.002659/97-02, permits no. 056/2000 - DIFAS/DIREC and no. 021/2002 COEFA. Nematodes were recovered from the small intestine of one specimen of Dasyprocta fuliginosa in the middle and high Negro river microregion, State of Amazonas, Brazil. The animal was captured in piassaba palm trees (Leopoldinia piassaba Wallace, 1853) plantations, maintained in the waterways of the Aracá river, left-side tributary of Negro river, Barcelos municipality. Worms, briefly kept in a $0.85 \% \mathrm{NaCl}$ solution, were fixed with steaming A.F.A ( $70^{\circ}$ GL ethanol, 93\%; formaldehyde, $5 \%$; glacial acetic acid, 2\%) and stored as wet material in the same solution; some were further dehydrated in an ethanol series, clarified in glacial acetic acid, phenol and preserved as whole mounts in beechwood creosote and Canada balsam. Type material is deposited in the Coleção Helmintológica do Instituto Oswaldo Cruz (CHIOC). The synlophe was studied according to the Durette-Desset (1985), Durette-Desset \& Digiani (2005) methods. The cuticular ridges are numbered from left to right for the dorsal and for the ventral sides, the sides being delimited by the lateral fields. The nomenclature used for the study of the caudal bursa follows Durette-Desset \& Chabaud (1981). Classification of the host is in accordance with Woons (1993). Figures were made with the aid of a drawing tube connected to a bright-field microscope. Measurements are in micrometers $(\mu \mathrm{m})$ unless otherwise indicated.

\section{RESULTS}

\section{Viannaiidae Durette-Desset \& Chabaud, 1981 Viannaiinae Neveu-Lemaire, 1934 Viannella trichospicula sp. nov. Figs $1-14$}

Type material. Holotype male and allotype female CHIOC no. 35419 (wet material), male paratypes no. 35420 (wet material), female paratypes no. 35421 (wet material), male and female paratypes CHIOC no. 34857 (wet material) and $35052 \mathrm{a}-\mathrm{k}$ (whole mounts).

Type host. Dasyprocta fuliginosa Wagler, 1832 (Dasyproctidae). Necropsy CHIOC no. 26465.

Site of infection. Small intestine.

Type locality. Três Barracas settlement, Jauari waterway, left margin of the Aracá river, Barcelos municipality ( $0^{\circ} 58^{\prime} 29^{\prime \prime} \mathrm{S}$, $\left.62^{\circ} 55^{\prime} 27^{\prime \prime} \mathrm{W}\right)$, State of Amazonas, Brazil.

Collector/date. A.Q. Gonçalves, February 06, 2002.

General. Small and fragile nematodes coiled along ventral side following two to three spirals in male, three in female. Cuticle strongly dilated on right ventral and left dorsal quadrant. Nerve ring difficult to observe; often, only nervous cells are visible. Excretory pore situated within proximal third of oesophagus in males, within third quarter in females. Deirids well developed, tongue-shaped (Fig. 6), situated at same level as excretory pore, slightly anterior or posterior to it. Oesophagus less than $13 \%$ of body length in males, $14 \%$ in females. In males, papillae 1 are very long (Figs 10,11). In females, infundibulum rectilinear (Fig. 13) or twisted (Fig. 14) and in this case, not measurable, posterior genital branch present but atrophied (Figs 13, 14). Uterus between $9 \%$ and $15 \%$ of body length.

Head. Cephalic vesicle present. In apical view triangular mouth opening surrounded by two amphids, four externo-labial papillae and four cephalic papillae (Fig. 1).

Synlophe. (studied in one male, one female paratype). In both sexes cuticle bears uninterrupted longitudinal cuticular ridges. Ridges appear posterior to cephalic vesicle except dorsal ridge no. 5 , ventral ridge no. 7' both arising between cephalic vesicle and nerve ring (Figs 7,8 ) and ridge no. $1^{\prime}$ arising posterior to excretory pore (Fig. 5). In male, dorsal ridges disappear about 300 anterior to caudal bursa and ventral ridges about 100. In female, ventral ridges disappear 50-60 anterior to vulva and dorsal ridges at vulvar level. Right ventral quadrant and left dorsal quadrant without ridges. Number of ridges along the body except for the extremities: 11 (4 dorsal, 7 ventral) in male (Figs 3, 4), 12 (5 dorsal, 7 ventral) in female (Fig. 2 ). Gradient of size present on ventral side and decreasing from 

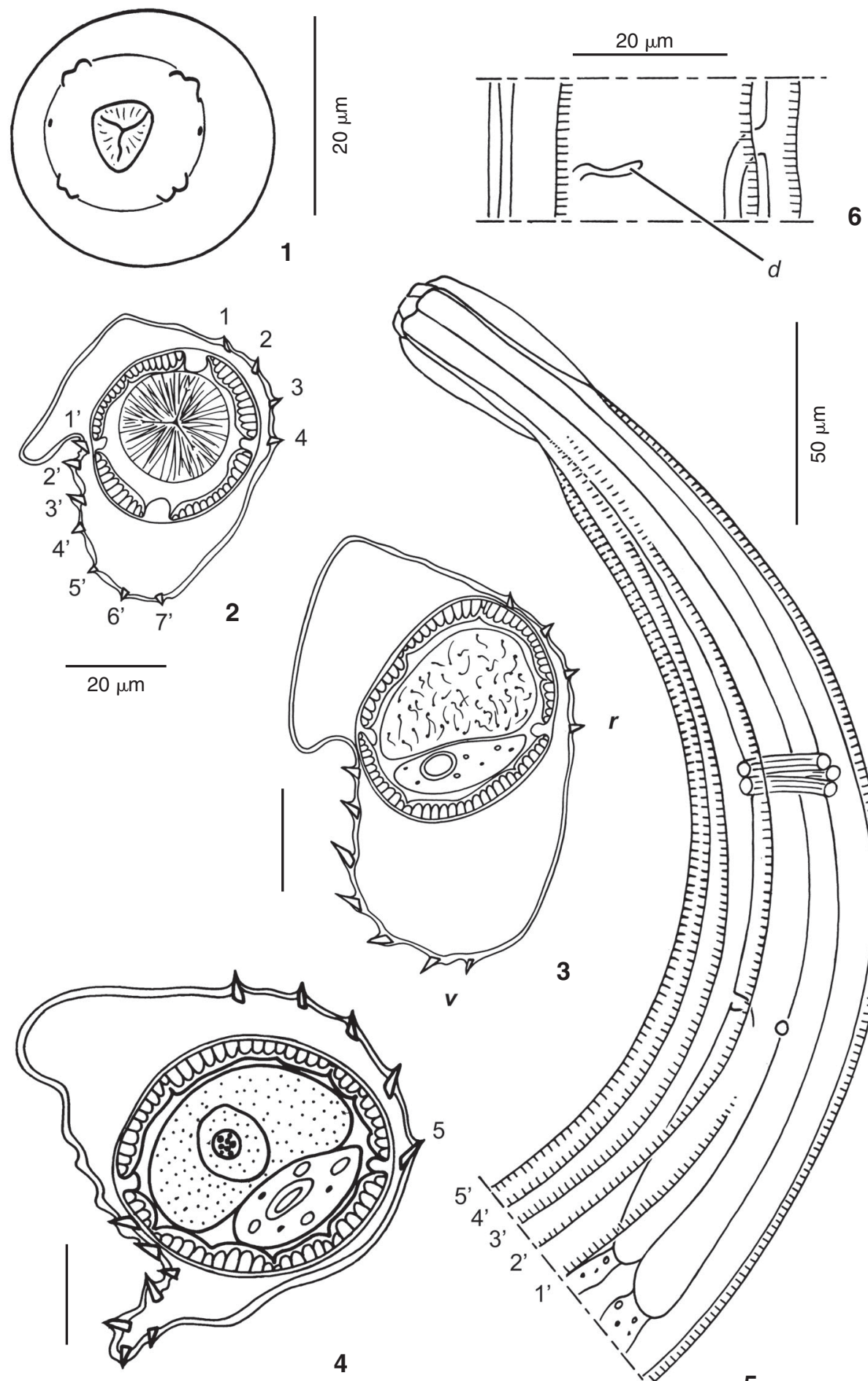


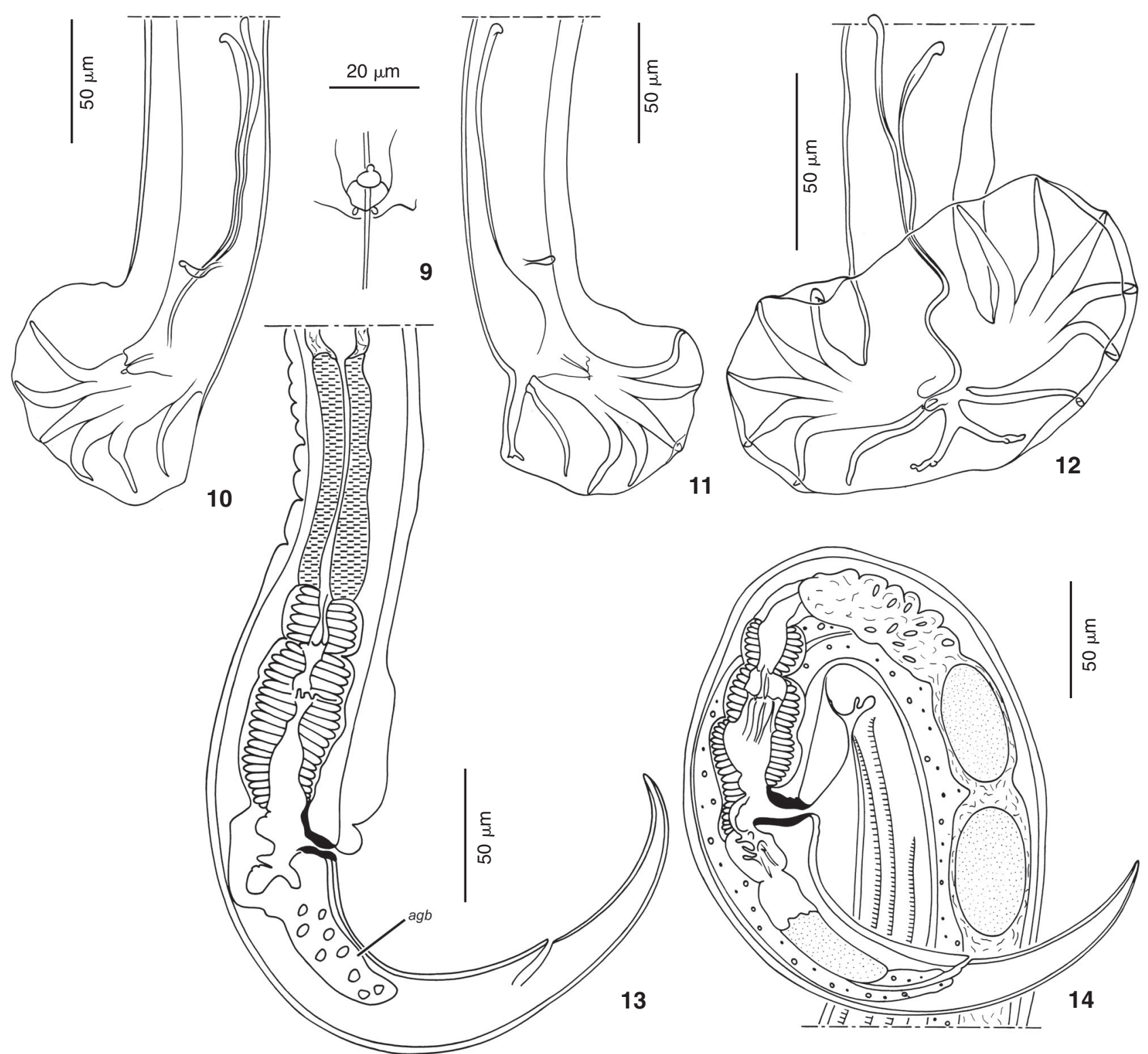

Figures 9-14. Viannella trichospicula sp. nov.. (9-12) Male: (9) genital cone, ventral view; (10-12) caudal bursa; (10) left lateral view; (11) right lateral view; (12) another male, ventral view; (13-14) Female: (13) posterior extremity, right lateral view; (14) another female, posterior extremity, right lateral view. (agb) Atrophied genital branch.

left to ventral side. Dorsal ridges of equivalent size. At midbody, axis of orientation directed from right ventral quadrant to left dorsal quadrant and inclined at about $40^{\circ}$ to sagittal axis in male, $45^{\circ}$ in female.

Holotype male. $2.3 \mathrm{~mm}$ long, 70 wide, cuticular dilatation included. Cephalic vesicle 50 long and 25 wide. Nerve ring, excretory pore and deirids situated at 140, 205 and 210 from apex, respectively. Oesophagus 320 long. Caudal bursa slightly asymmetrical with larger left lobe and pattern of type 1-4 with tendency 1-3-1, with ray 2 diverging first from common trunk, then rays 6 (Figs 10-12). Papillae 1 about $12 \mu \mathrm{m}$ long. Rays 3 to 5 separated at same level from their common trunk. Rays 3 most developed. Dorsal lobe poorly developed with long rays 8 arising at base of dorsal ray. Dorsal ray divided within its median third into two branches forming an open "V". Each branch divided into two small branches, rays 9 (external branches) and rays 10 reduced to a button (internal branches). Extremely thin spicules, 150 long with handle about $1 / 4$ of spicule length. Each 
spicule ending in one tip (Figs 10-12). Ratio spicule length/ body length 6. 5\%. Rectangular genital cone, 20 long, 10 wide on ventral view with 2 small rounded papillae 7 on ventral lip (Fig. 9). Papilla zero not observed. Gubernaculum absent.

Main measurements (average and range) of 8 paratypes. 2.4 (2.1-2.7) $\mathrm{mm}$ long, 71 (60-85) wide; cephalic vesicle 53 (50$58)$ long and $23(20-26)$ wide; nerve ring $(n=7)$, excretory pore $(\mathrm{n}=7)$ and deirids $(\mathrm{n}=7)$ situated at $138(120-170), 213(175$ 230), 216 (175-238) from apex, respectively; oesophagus 295 (270-310) long; spicules 144 (135-160) long. Ratio spicule length/body length 5.9\% (5-4 -7.1) \%

Allotype female. $2.9 \mathrm{~mm}$ long, 75 wide, cuticular dilatation included. Cephalic vesicle 75 long, 25 wide. Nerve ring, excretory pore and deirids at 180, 225 and 230 from apex, respectively. Oesophagus 310 long (Fig. 5). Monodelphic. Vulva situated at 220 from caudal extremity; vagina vera 22 long, ovejector very short, 105 long with vestibule 50 long, 30 wide, sphincter 20 long, 30 wide, infundibulum 45 long (Fig. 13). Uterus 440 long with 7 eggs, 8 to 16 blastula stage, 50 long, 25 wide; ratio uterus length/ body length: $15.2 \%$. Atrophied posterior genital branch, 60 long (Figs 13, 14). Very thin tail, with sharp tip, 80 long (Figs 13, 14).

Main measurements (range and average) of 8 paratypes. 3.2 (2.8-3.5) long, 71 (60-80) wide; cephalic vesicle 51 (50-55) long, 27 (23-32) wide; nerve ring $(\mathrm{n}=5)$, excretory pore and deirids situated at 173 (160-200), 217.5 (190-255) and 216 (200235) from apex, respectively; oesophagus 341 (300-400) long; vulva situated at 219 (200-230) from caudal extremity; vestibule 40 (36-60) long; sphincter $(n=6) 27$ (20-30) long, 34 (3036) wide, infundibulum $(\mathrm{n}=3) 70(60-80)$; uterus long; eggs 5 (4-7), 55 (50-60) long, 30 (25-36) wide; atrophied posterior uterine branch 90 (65-115) long; tail 83 (70-90) long.

Diagnosis. The specimens described above, belong to the genus Viannella Travassos, 1918 (Viannaiidae, Viannaiinae) which is mainly characterized by a monodelphic female and a synlophe without ridges on the right ventral and left dorsal sides, the pattern of the caudal bursa being variable. Seven species are described in the genus, all in the Neotropical region, six in Caviomorpha rodents (one in the Hydrochoeridae Gray, 1825, one in the Agoutidae Gray, 1821, one in the Chinchillidae Bennet, 1833 and three in the Caviidae Gray, 1821) and one in Primates.

The parasites from specimens of Dasyprocta Illiger, 1811, are differentiated from the other species of the genus by the extreme slenderness of the spicules. They therefore belong to the new species described here Viannella trichospicula sp. nov., taking into account this character.

Remarks. On what concerns other morphological features, two species, V. brevispicula Lent \& Freitas, 1936 (Lent \& Freitas 1936) a parasite of Agouti paca (Linnaeus, 1756) from Brazil and V. dubia (Travassos, 1921) (Travassos 1921) a parasite of Cebidae spp. from South America are close to V. trichospicula sp. nov.

In the original description of $V$. brevispicula, the spicules are untwisted and relatively thick. On what refers to the synlo- phe, Durette-Desset (1968) figured a section at mid-body of a voucher male parasite of Agouti paca from Brazil; nevertheless, there was no information about the spicules and the caudal bursa. The pattern of the synlophe is similar to that of the male of $V$. trichospicula sp. nov. (4 dorsal cuticular ridges of equivalent size, 7 ventral with a decreasing gradient of size from left to right). There is a strong probability that the male drawn by DuretTeDesset (1968) belongs to the species $V$. trichospicula sp. nov.

The closest related species is Viannella dubia described as Heligmosomum dubium Travassos, 1921 in Alouatta caraya (Humboldt, 1812) from Brazil (Travassos 1937, Vicente et al. 1997). The species was recorded in two other South American Cebidae, Saimiri sciureus (Linnaeus, 1758) by CAMEron (1923) and Callithrix jacchus (Linnaeus, 1758) by Mawson (1964), but the precise geographic locality of these hosts is unknown, since they were kept in zoological gardens. The number of cuticular ridges is about the same ( 5 dorsal, 7 ventral in male, unknown in female). The caudal bursa is also of type 1-4, the spicules are straight and untwisted and the distance anus-vulva is twice as great as the length of the tail. Finally, it is the only other species in the genus to possess an atrophied posterior genital branch. Therefore, the presence of the genus Viannella Travassos, 1918 in primates is interpreted as a "capture" from a species close to Viannella trichospicula sp. nov.

\section{Avellaria intermedia sp. nov. Figs 15-36}

Type material. Holotype male and allotype female CHIOC no. 35416 (wet material), male paratypes no. 35417 (wet material), female paratypes no. 35418 (wet material), male and female paratypes CHIOC no. 34883 (wet material) and $35072 \mathrm{a}-\mathrm{g}$ (whole mounts). 26465.

Type host. Dasyprocta fuliginosa. Necropsy CHIOC no.

Site of infection. Small intestine.

Type locality. Três Barracas settlement, Jauari waterway, left margin of the Aracá river, Barcelos municipality (058'29"S, $\left.62^{\circ} 55^{\prime} 27^{\prime \prime} \mathrm{W}\right)$, State of Amazonas, Brazil.

Collector/date: A. Q. Gonçalves/ February 06, 2002.

Description:

General. Small nematodes coiled along ventral side forming two spirals in both sexes. In females, only the anterior part of the body is coiled up to level of the vulva; the posterior part is straight, producing a very peculiar silhouette (Fig. 25). Just anterior to vulva, body widens and forms a "bubble" of 280 long, 330 wide on average (Figs 25, 26). In males, body widens progressively to the level of caudal bursa (Fig. 31). Excretory pore within median third of oesophagus in female, distal third in male. Rounded deirids, posterior to excretory pore (Fig. 24). Oesophagus length less than $12 \%$ of body length. In males, papillae 1 well-developed (Fig. 30B). In females, vulva situated between third and posterior quarter of body; each sphincter divided into two triangular parts by a median constriction, 


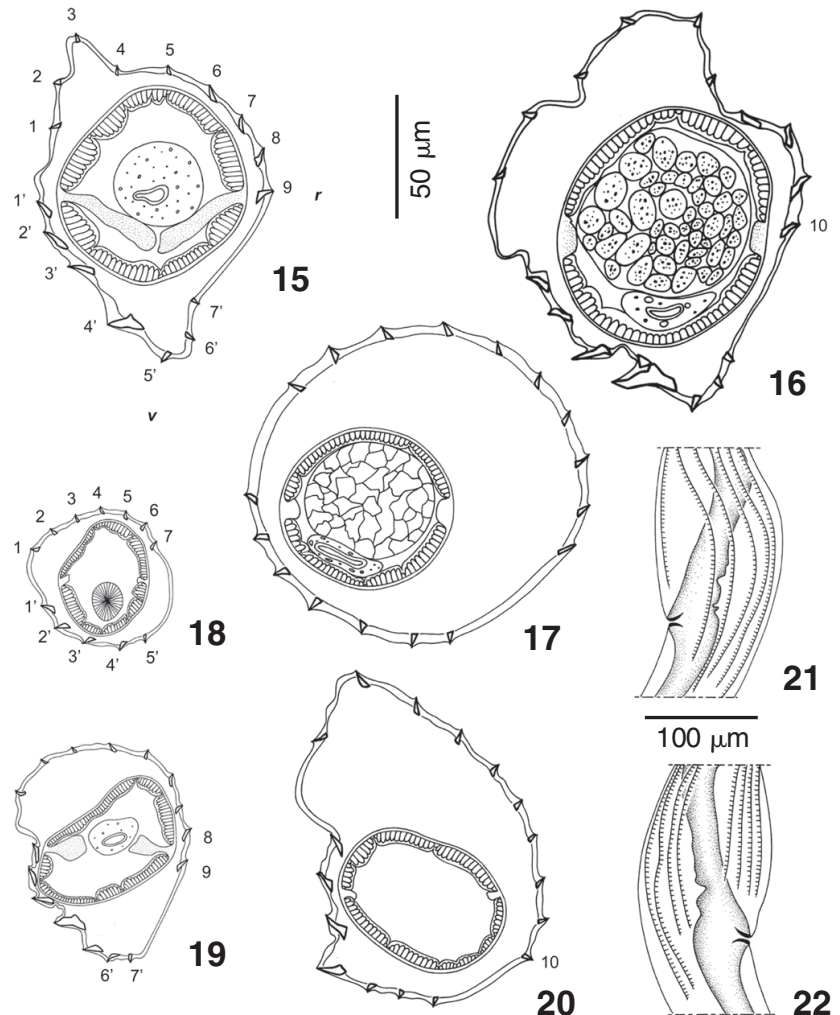

Figures 15-22. Avellaria intermedia sp. nov.: (15-20) transverse sections of the body; (15-17) male 4.5 long; (15) at oesophagointestinal junction; (16) at mid-body (1.9 mm from apex); (17) at posterior third of body (3.0 mm from apex); (18-20) female 4.4 $\mathrm{mm}$ long; (18) just posterior to cephalic vesicle; (19) at oesophagointestinal junction; (20) at mid-body (2 mm from apex); (21, 22) other female, disappearance of the ridges at vulvar level; (21) left lateral view; (22) right lateral view. (v) Ventral side, ( $r$ ) right side. Bars: (15-20) $50 \mu \mathrm{m}$; (21-22) $100 \mu \mathrm{m}$.

named part 1 for infundibulum side and part 2 for vestibule side. Ratio uterine branches length/body length between $16.2 \%$ and $26 \%$ for the anterior branch, $12.7 \%$ and $18 \%$ for the posterior. In some paratype females, the presence of a vulvar "cork" was observed (Fig. 26).

Head. Cephalic vesicle present. In apical view, presence of six small lips surrounded by two amphids, six externo-labial papillae and four cephalic papillae (Fig. 23).

Synlophe. (studied in one male and one female paratype) (Figs 15-22). In both sexes, cuticle with longitudinally uninterrupted ridges. Ridges appearing posterior to cephalic vesicle and at different levels, opposite right lateral field, up to anterior third of body. Ridges disappearing between 250 to 300 anterior to caudal bursa in male. In female, ventral ridges disappearing just anterior to vulva, dorsal ridges just posterior to the vulvar aperture (Figs 21, 22). No ridges on the right region of the right ventral side and on part of left region of the left dorsal side. Number of ridges. In both sexes, just posterior to cephalic vesicle, 12 (7 dorsal, 5 ventral) (Fig. 18), at level of oesophago-intestinal junction, 16 (9 dorsal, 7 ventral) (Figs 15, 19); at anterior third of body and mid-body 17 (10 dorsal, 7 ventral) (Figs 16, 20). This number remains the same until the ridges disappear (Fig. 17). In anterior part of body, ridges of unequal size, dorsal ridges being smaller than ventral ones. On left ventral side, size of ridges decrease from both ventral to left and right sides. In posterior part of body, size of ridges decreases from the level of posterior quarter of body in males and from the level of vulva in females where ridges are of equivalent size (Fig. 17). All along body, tips of ridges are directed from right ventral to left dorsal side. At mid-body, axis of orientation inclined at about $55^{\circ}$ to sagittal axis for both sexes on right axis (Figs 16, 20), not calculable on the left side.

Holotype male. $3.9 \mathrm{~mm}$ long, 150 wide at mid-body, 185 anterior to caudal bursa; cephalic vesicle 90 long, 40 wide; nerve ring, excretory pore and deirids situated at 250, 350 and 370 from apex, respectively; oesophagus 425 long (Fig. 24). Caudal bursa with pattern of type 1-3-1 (rays 2 and 6 separating first from common trunk of rays 2 to 6 (Figs 29-32). Papillae 1, 70 long. Rays 2 and 3 totally separated up to base. Rays 4 longest, very thick, rounded at extremity. Rays 8 arising just anterior to division of dorsal ray. Dorsal ray divided into two branches forming at base an angle of $90^{\circ}$. Each branch ending in one round tip, rays 9 (external branches) and rays 10 (internal branches) confused. Spicules 270 long; ratio of spicules length to body length $6.9 \%$ (Figs 33-35). Each spicule with a small curved handle 48 long and blade ending in one tip, slightly longer in left spicule. Tips encircled by a membrane. In one paratype, the genital cone 15 long and 30 wide at base with papilla zero on ventral lip and long papillae 7 on dorsal lip (Fig. 36). Gubernaculum absent.

Main measurements (average and range) of 9 paratypes: 4 (3. 5-4.3) mm long; 135 (110 -150) wide at mid-body and 180 (160-200) anterior to caudal bursa; nerve ring ( $\mathrm{n}=5)$, excretory pore $(n=6)$ and deirids $(n=4)$ situated at $276(175$ 280), 325 (280 -360), 330 (310-365) from apex, respectively; oesophagus: 420 (410-450) long; spicules: 296 (270-310) long. Ratio of spicules length to body length $8 \%$ (6.7-8.9\%).

Allotype female. $5.9 \mathrm{~mm}$ long and 150 wide at mid-body, 200 anterior to vulva, 100 posterior to vulva. Cephalic vesicle 75 long, 40 wide; nerve ring, excretory pore and deirids situated at 200, 290 and 310 from apex, respectively; oesophagus 525 long. Didelphic: vulva at $1.3 \mathrm{~mm}$ from caudal extremity, $27.8 \%$ of body length. Vagina vera 28 long. Ovejector 362 long, vestibule 80 long with very small distal part, anterior sphincter 50 long with part 1 measuring 20 long, 32 wide and part 2, 30 long, 42 wide, anterior infundibulum 80 long. Posterior sphincter 75 long with part 1 measuring 20 long, 30 wide and part 2, 30 long, 45 wide, posterior infundibulum 60 long (Fig. 26). Anterior uterine branch $1.2 \mathrm{~mm}$ with 14 eggs, posterior 


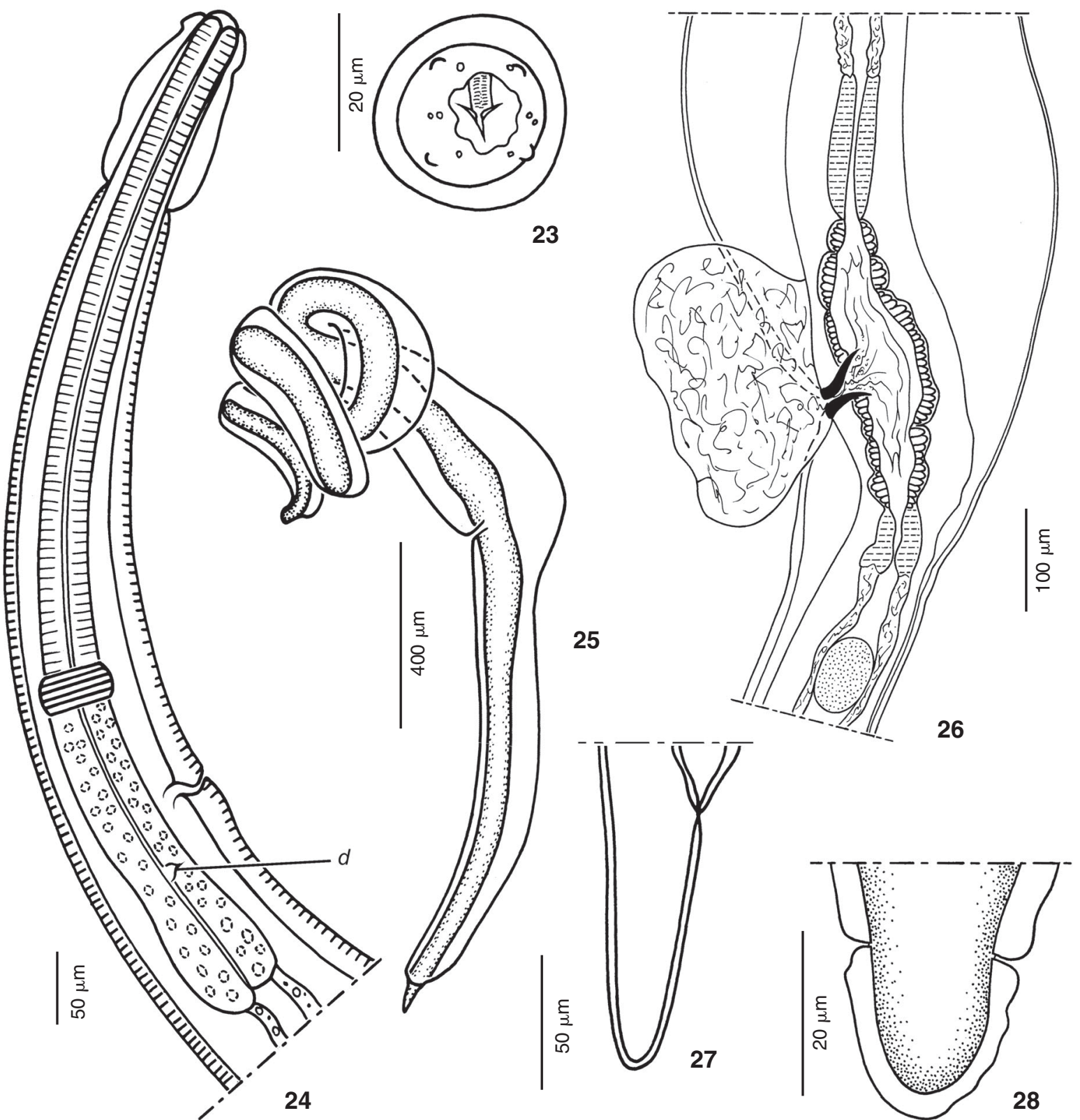

Figures 23-28. Avellaria intermedia sp. nov.: (23) female, head, apical view; (24) male, anterior extremity, right lateral view; (25) female, silhouette showing the coiled anterior part of the body, the swelling of the cuticle at the level of the vulva and the straight posterior part of the body, left lateral view; (26) female, ovejector and vulvar "cork", left lateral view; (27) female, tail, right lateral view; (28) female, rounded caudal extremity with the phasmids. (d) Deirids.

uterine branch 750 long with 19 eggs, 50 long, 30-35 wide. Ratio of anterior uterine branch to body length: $20.8 \%$, posterior $12.5 \%$. Tail 60 long, 35 wide at base with rounded extremity (Figs 27-28).

Main measurements (average and range) of 9 paratypes. Length 4.9 (4.0-5.4) mm; width at mid-body, 136 (110-160), anterior to vulva 278 (250-350), posterior to vulva 138 (125150), cephalic vesicle 69 (62-80); nerve ring, excretory pore and deirids $(\mathrm{n}=7)$ situated at $206(180-250), 286(235-325)$, 292 (255-343) from apex, respectively; oesophagus 486 (445520) long; vulva at 1.4 (1.1-1.5) from caudal extremity; ovejector with vestibule 73 (60-82) long; anterior sphincter $(n=7) 48$ 

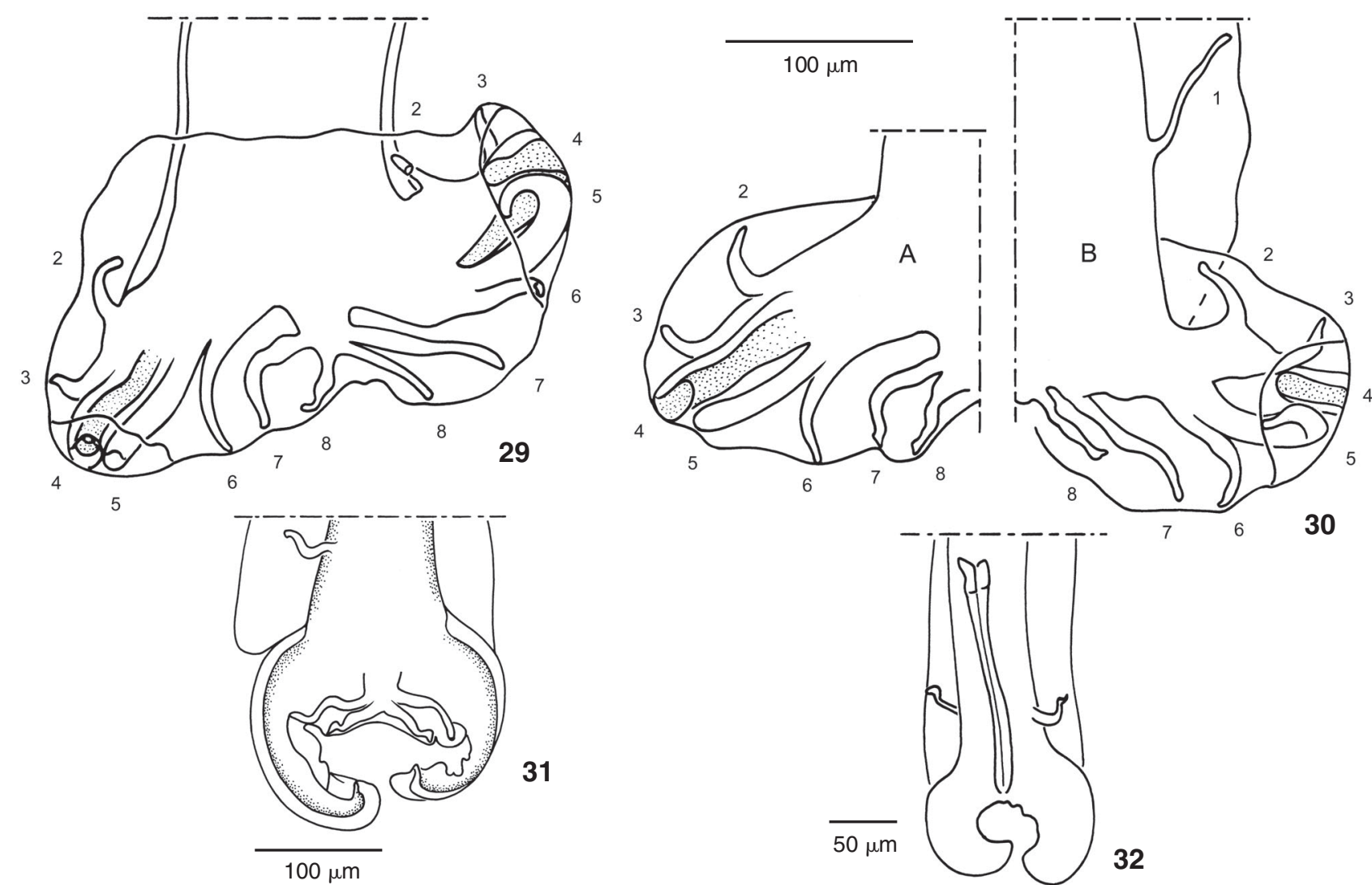

$100 \mu \mathrm{m}$

31

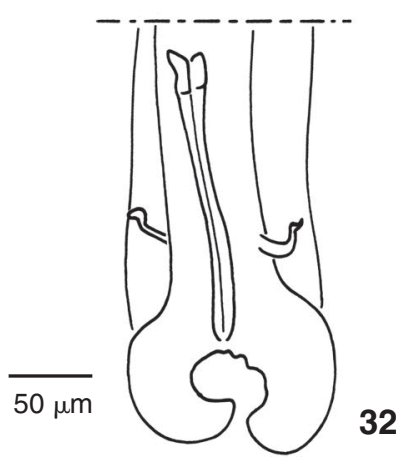

Figures 29-32. Avellaria intermedia sp. nov.: (29) male caudal bursa, ventral view; (30 A) right lobe, ventral view; (30 B) left lobe, ventral view; (31-32) other male; (31) dorsal view showing dorsal lobe; (32) silhouette of posterior part showing papillae 1.

(42-50) long with part 1 measuring 21 (20-27) long, 35 (28-45) wide, part 2, measuring 27 (22-30) long, 46 (35-56) wide; anterior infundibulum $65(50-85)$ long; posterior sphincter $(\mathrm{n}=8)$ 45 (39-52) long with part 1 measuring 20 (17-22) long, 32 (26$50)$ wide and part 2, 25 (22-33) long, 45 (38-50) wide for part 2; posterior infundibulum $(\mathrm{n}=5) 57(48-75)$ long. Anterior uterine branch $(\mathrm{n}=7) 1.020$ (730-1300) long with $4(0-14)$ eggs, posterior uterine branch $(\mathrm{n}=8) 800(640-1100)$ long with $8(0-$ 22) eggs 48 (40-55) long, 28 (20-35) wide; tail 91 (82-115) long, 37 (30-45) wide at base; Ratio of anterior uterine branch to body length $(\mathrm{n}=7) 18.4(16.2-26.3) \%$; Ratio of posterior uterine branch to body length $(\mathrm{n}=7) 15.6(12.7-18.2) \%$. Tail 91 (82-115) long, 37 (30-45) at base. Phasmids visible (Fig. 28).

Diagnosis. The specimens described above belong to the super-family Heligmosomoidea, considering that the body is coiled in a sinistral spiral and the synlophe is not symmetrically bilateral (Durette-Desset \& Chabaud 1993). They present the same features as the Viannaiidae, mainly parasites of Neotropical marsupials, Cavioidea and Chinchilloidea rodents (one species in a primate). The Viannaiidae parasites of marsupials are characterized by a synlophe with three left ventral ridges or ridges with a subfrontal axis of orientation and didelphic females. The Viannaiidae parasites of rodents are characterized by a synlophe with an oblique axis of orientation in relation to the sagittal axis and monodelphic females. The nematodes recovered from specimens of Dasyprocta present didelphic females like the Viannaiidae parasites of marsupials and a synlophe similar to that of the parasites of rodents. It would, therefore, seem necessary to include these specimens in another genus.

Freitas \& Lent (1934) described a new genus Avellaria for a species parasite of Agouti paca from Brazil named A. avellari. The description of the male of this species is similar to that of the specimens described above: caudal bursa with stout rays 4 of which the extremities are wide and rounded, dorsal ray and rays 8 of similar shape, spicules relatively long and straight, opposite to the twisted spicules of the genus Viannella. Therefore, the male parasite of $A$. paca and those described above are different from the species of the genus Viannella and belong to another genus.

The female parasite of $A$. paca described by FreITAS \& LenT (1934) as A. avellari is monodelphic and therefore does not belong to same genus as the male. It is relatively frequent in 

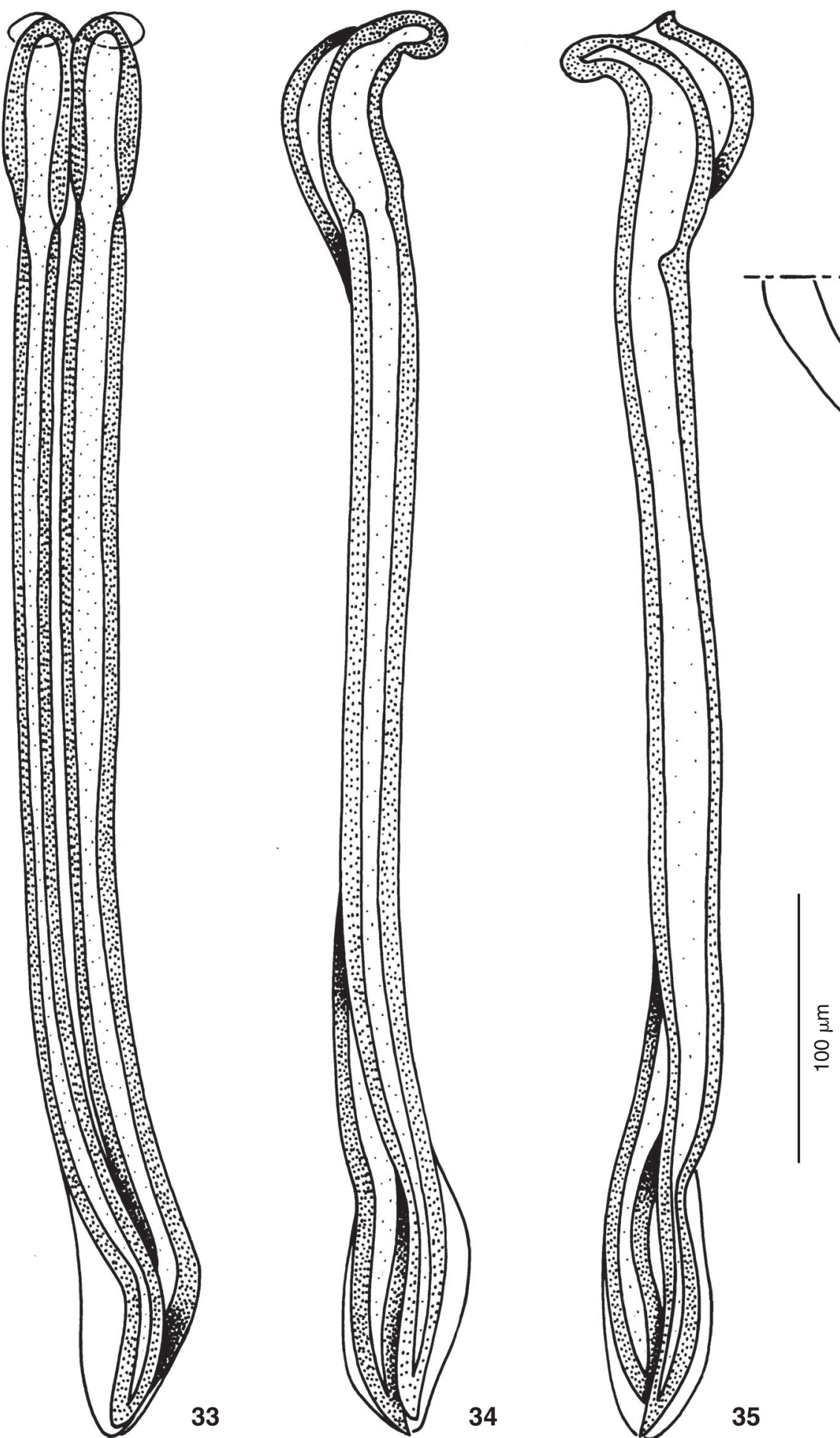

Figures 33-36. Avellaria intermedia sp. nov. (33-35) Dissected spicules of male: (33) dorsal view with left spicule on right hand side; (34) right lateral view with left spicule behind right spicule; (35) left lateral view with left spicule above right spicule; (36) genital cone, ventral view. (P. zero) Papilla zero, (P.7) papilla 7. 
the Heligmosomoidea and particularly in the Pudicinae that several congeneric species or genera belonging to the same evolutive line share the same infection site (small intestine). (Durette-Desset 1970a, b, R'Kha \& Durette-Desset 1990, Cassone \& Durette-Desset 1991). In this case, only the features of the synlophe allow us to match up the two sexes. The female described as $A$. avellari has a particular ovejector not described in the other monodelphic Viannaiidae and without the knowledge of the synlophe it is dificult to classify it. However, two features are close to the genus Viannella Travassos, 1918: firstly, the female presents an atrophied genital posterior branch as $V$. dubia Travassos, 1937 and $V$. trichospicula sp. nov. Secondly, the section of a female made at two-thirds of the body by DuretTE-Desset (1968) is similar to the synlophe of the genus Viannella and we think that it is possible to allocate this female in the genus Viannella.

The re-establishment of the genus Avellaria that was put in synonymy with Viannella by DuRETTE-DESSET (1968) is proposed. The nematodes found in the specimen of Dasyprocta are differentiated from the male of $A$. avellari by a smaller number of cuticular ridges (17 versus 27 ), a higher ratio of spicules length/ body length ( $8 \%$ versus $5.6 \%$ ) and spicules with a single tip.

Thus, some of the nematode specimens parasitizing the agouti investigated here are considered representatives of the new species described, Avellaria intermedia sp. nov., considering the intermediary position of the genus between the Viannaiidae parasites of marsupials and those which are parasites of rodents. The emendation of the definition of the genus Avellaria is: Viannaiidae, Viannaiinae with didelphic female; synlophe with ventral ridges strongly developed in anterior part of body, caudal bursa of type 1-3-1 with huge rays 4, straight spicules with small and marked handle. Parasites of Neotropical Agoutidae and Dasyproctidae.

Type species. Avellaria avellari Freitas and Lent, 1934. Other species: Avellaria intermedia sp. nov.

Remarks. It is the first report of a Viannaiinae in the genus Dasyprocta, only parasitized up to now by the Pudicinae (Heligmonellidae). According to Durette-Desset (1971), the Viannaiinae parasites of caviomorph rodents may have derived from the Viannaiinae parasites of marsupials and the diagnosis of genus Avellaria supports this hypothesis. The female is didelphic like the parasites of marsupials but the synlophe is similar to the observed in species of the genus Viannella with the presence of an oblique axis and the absence of cuticular ridges at least pro parte on the ventral-right and dorsal left sides.

\section{ACKNOWLEDGEMENTS}

To José R. Coura and Angela C.V. Junqueira, from the Laboratory of Parasite Diseases, Department of Tropical Medicine, Oswaldo Cruz Institute, Rio de Janeiro, Brazil for the invitation to collect the samples for this study. To the National Health Foundation; to Cibele R. Bonvicino and Gilson E. IackXimenes from the National Cancer Institute, Rio de Janeiro,
Brazil, and Zoology Museum of São Paulo University, respectively, for the identification of the rodent host; to Dely Noronha, Curator of the Helminthological Collection of the Oswaldo Cruz Institute (CHIOC), Rio de Janeiro, Brazil, for the loan of some helminthes specimens for study.

\section{REFERENCES}

Cameron, T.W.M. 1923. Studies on two new genera and some little known species of the nematode family Trichostrongylidae Leiper. Journal of Helminthology, Wallingford, 1 (2): 71-96.

Cassone, J. \& M.C. Durette-Desset. 1991. Cinq espèces (dont trois nouvelles) de Nématodes Trichostrongyloïdes coparasites de Dasyprocta azarae au Paraguay. Revue Suisse de Zoologie, Geneve, 98 (1): 229-242.

Durette-Desset, M.C. 1968. Nématodes Héligmosomes d'Amérique du Sud. III. Nouvelles données morphologiques sur 5 espèces parasites de Rongeurs ou de Primates. Bulletin du Museum National d'Histoire Naturelle, Paris, 2ème sér., 40 (6): 1215-1221.

Durette-Desset, M.C. 1970a. Nématodes Héligmosomes d'Amérique du Sud. VI. Etude de cinq espèces, parasites de Rongeurs Dasyproctidés Bulletin du Museum National d'Histoire Naturelle, Paris, 2ème sér., 42 (3): 590-600.

Durette-Desset, M.C. 1970b. Nématodes Héligmosomes d'Amérique du Sud. VII. Étude de trois espèces nouvelles, parasites de Proechimys semispinosus (Rongeurs Echimyidés). Bulletin du Museum National d'Histoire Naturelle, Paris, 2ème sér., 42 (3): 601-608.

Durette-Desset, M.C. 1971. Essai de classification des Nématodes Héligmosomes. Corrélation avec la paléobiogéographie des hôtes. Mémoires du Museum National d'Histoire Naturelle, Paris, nlle. sér., sér. A, Zool., 49: 1-126.

DuretTe-Desset, M.C. 1985. Trichostrongyloid nematodes and their vertebrate hosts: reconstruction of the phylogeny of a parasitic group. Advances in Parasitology, New York, 24: 239-306.

Durette-Desset, M.C. \& A.G. Chabaud. 1981. Nouvel essai de classification des Nématodes Trichostrongyloidea. Annales de Parasitologie Humaine et Comparée, Paris, 56 (3), 297-312.

Durette-Desset, M.C. \& A.G. Chabaud. 1993. Note sur la nomenclature suprafamiliale des Strongylida. Annales de Parasitologie Humaine et Comparée, Paris, 68: 11-112.

Durette-Desset, M.C. \& M.C. Digiani. 2005. The axis of orientation of the synlophe in the Heligmosomoidea (Nematoda, Trichostrongylina). New approach. Parasite, Paris, 12: 195202.

Durette-Desset, M.C.; E. Deharo; J.L. Santivanez-Galarza \& A.G. Chabaud. 2001. New Pudicinae (Trichostrongylina, Heligmosomoidea) coparasites of Proechimys longicaudatus (Caviomorpha) from Bolivia I - Description of Pudica ginsburgi sp. nov. and Heligmostrongylus chiarae sp. nov. Parasite, Paris, 8: 223-230.

Freitas, J.F.T. \& H. Lent. 1934. Novo nematódeo da subfamília

Revista Brasileira de Zoologia 23 (2): 509-519, junho 2006 
Heligmosominae Travassos, 1914, parasito de Agouti paca (L.): Avellaria avellari n. gen. sp. nov. Memórias do Instituto Oswaldo Cruz, Rio de Janeiro, 28 (4): 577-583.

Guerrero R. 1982. Trichostrongyloidea (Nematoda) parasitos de mamiferos silvestres de Venezuela. I. Los generos Bradypostrongylus Price, 1928; Longistriata Schulz, 1926 y Durettestrongylus n. gen. Acta Biologica Venezuelica, Caracas, 11 (3): 111-131.

LaInson, R. 1997. On Leishmania enriettii and other enigmatic Leishmania species of the neotropics. Memórias do Instituto Oswaldo Cruz, Rio de Janeiro, 92 (3): 377-387.

Lent, H. \& J.F.T. Freitas. 1936. Novo parasito de Agouti paca (L.) (Nematoda: Strongyloidea). Memórias do Instituto Oswaldo Cruz, Rio de Janeiro, 31 (2): 357-359.

Nerva, A.; A. M. Cunha \& L. Travassos. 1914. Contribuições parazitolojicas. Memórias do Instituto Oswaldo Cruz, Rio de Janeiro, 6:180-191.

Mawson, P.M. 1964. Two trichostrongyle nematodes from a marmoset. Transactions of the Royal Society of South Australia, Adelaide, 88: 157-159.

Rebollar-Telles, E.A. F.J.Andrade-Narvaez, I. Fernandez-Salas, F. Reys-Villanueva. 1996. Collections of sand flies (Diptera: Psychodidae) from mammal burrows in an area of cutaneous leishmaniasis in Campeche, Mexico. Entomological News, Richmond, 107: 5, 317-321.

Ribeiro, R.D. \& M.P. BARRETTO. 1977. Estudos sobre reservatórios e vetores silvestres do Trypanosoma cruzi. LXV. Infecção natural da cutia, Dasyprocta aguti (Linnaeus, 1766) pelo T. cruzi. Revista Brasileira de Biologia, Rio de Janeiro, 37: 2.

R'Kha S. \& M.C. Durette-Desset. 1990. Trois espèces (dont deux nouvelles) de Nématodes Trichostrongyloïdes parasites de
Proechimys semispinosus en Colombie; description de Justinema n. gen. Bulletin du Museum National d'Histoire Naturelle, Paris, 4e sér., 12, sect. A (3/4): 555-562.

Rodrigues-Silva, R.; J.R.V. Peixoto; R.M.F. Oliveira; R.M. Pinto \& D.C. Gomes. 2002. An autochthonous case of Echinococcus vogeli Rausch \& Bernstein, 1972 polycystic echinococcosis in the State of Rondônia, Brazil. Memórias do Instituto Oswaldo Cruz, Rio de Janeiro, 97 (1): 123-126.

Sherlock, I.A. 1996. Ecological interactions of visceral leishmaniasis in the State of Bahia, Brazil. Memórias do Instituto Oswaldo Cruz, Rio de Janeiro, 91 (6): 671-683.

Travassos, L. 1917. Nematodes parasitos de roedores. Brazil Medico, Rio de Janeiro, 31(3): 35.

Travassos, L. 1918. Trichostrongylidae brasileiras. Sociedade Brasileira de Sciencias, Rio de Janeiro, 3: 191.

Travassos, L. 1921. Contribuições para o conhecimento da fauna helmintológica brasileira. XIII. Ensaio monográfico da família Trichostrongylidae Laiper, 1912. Memórias do Instituto Oswaldo Cruz, Rio de Janeiro, 13 (1): 1-135.

Travassos, L. 1937. Revisão da família Trichostrongylidae Leiper, 1912. Rio de Janeiro, Instituto Oswaldo Cruz, VII+512p.

Travassos L. \& A.R. Darriba. 1929. Notas sobre Heligmosominae. Sciencia Medica, Rio de Janeiro, 7: 432-438.

Vicente, J.J.; H.O. Rodrigues; D.C.Gomes \& R.M. Pinto. 1997. Nematóides do Brasil. Parte V: Nematóides de Mamíferos. Revista Brasileira de Zoologia, Curitiba, 14 (Supl. 1): 1-452.

Woods, C.A. 1993. Suborder Hystricognathi, p. 771-806. In: D.E. Wilson \& D.M. REEDER (Eds). Mammal species of the world. A taxonomic and geographic reference. Washington, Smithsonian Institution Press, XVIII+1206p.

Received in 17.VIII.2005; accepted in 16.V.2006. 